
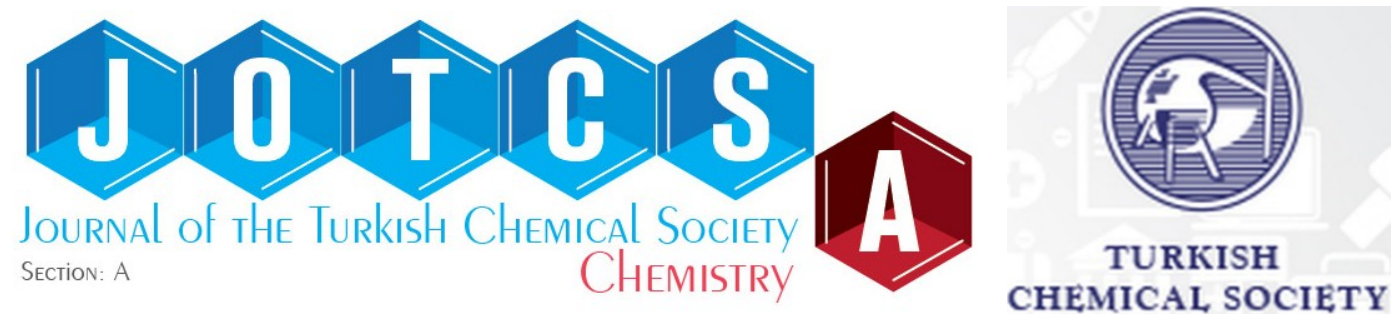

\title{
A Novel Conjugated Pyrene-BODIPY Dyad: Synthesis, Characterization and Properties
}

\author{
Husniye Ardic Alidagi* $\triangle D$, Seda Cetindere $\triangle D$ \\ Gebze Technical University, Faculty of Science, Department of Chemistry, 41400, Kocaeli, Turkey.
}

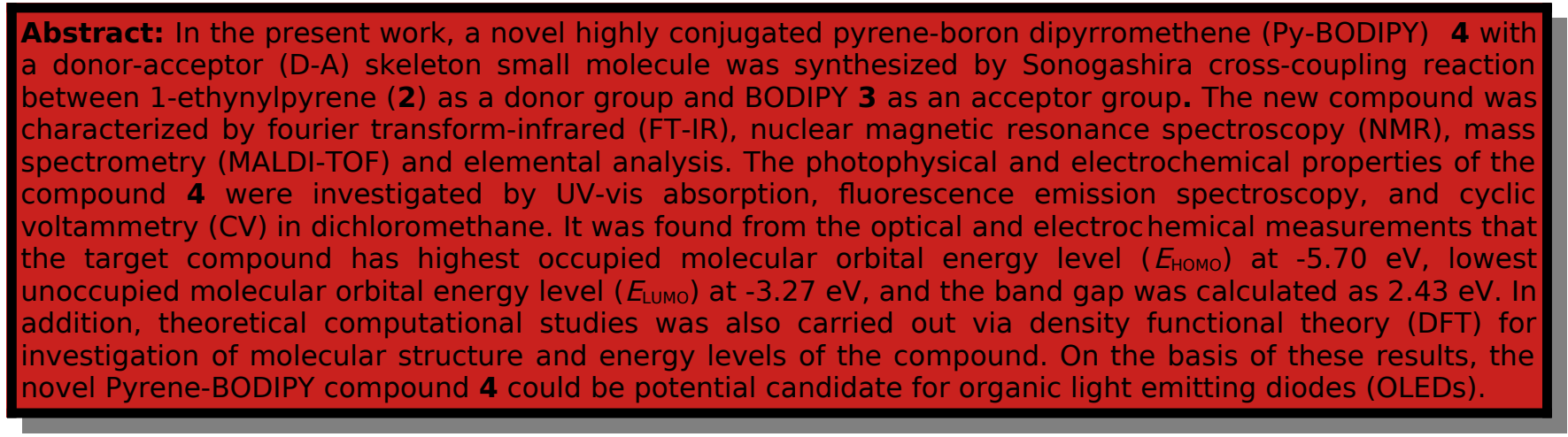

Keywords: Pyrene, BODIPY, optoelectronic device.

Submitted: November 20, 2020. Accepted: January 12, 2021.

Cite this: Ardic Alidagi H, Cetindere S. A Novel Conjugated Pyrene-BODIPY Dyad: Synthesis, Characterization and Properties. JOTCSA. 2021;8(1):311-20.

DOI: https://doi.org/10.18596/jotcsa.819632.

*Corresponding author. E-mail: hardic@gtu.edu.tr.

\section{INTRODUCTION}

Two or more chromophore containing supramolecular systems have attracted the interest of the world of science, because of their potential for significant applications ranging from energy transfer to optoelectronic devices and sensors $(1,2)$. This interest have caused the synthesis and characterization of a wide range of molecules placed with different chromophores chosen for their characteristic photophysical and electrochemical features. Investigation of photophysical properties of such compounds is especially fascinating and extremely dependent on the functional dye systems (3). Among many organic dyes, boron dipyrromethene (BODIPY) dyes have an importance as a fluorophore with many advantages including high quantum yield, high extinction coefficient, narrow emission bandwidth, and so, insensitivity to $\mathrm{pH}$ and solvent polarity, and considerable chemical and photochemical stabilities in solid state and in solution (4-6). BODIPYs are widely applied as fluorophores and, if combined with an appropriate electron donor or acceptor units like as pyrenes exhibit efficient electron or energy transfer (7-9). In addition, BODIPYs are excellent candidates as a $\pi-$ acceptor building block for optoelectronic applications due to the planar dipyrromethene core may ensure $\pi-\pi$ stacking with delocalized HOMOLUMO orbitals, large dipole moment in the range of 3-5 Debye, oriented toward the fluorine groups, could enhance thin film ordering by strong dipolar interactions, and also $\alpha, \beta$ or meso positions are easily functionalized for enhancing the conjugation or solution processibility (10).

Pyrenes are also an important part of the fluorophore family because of their unique photophysical properties and abilities to create an excimer caused to common use as a fluorescent label in different macromolecules (11-13). In the UV region, it has a high molar extinction coefficient and 
absorption spectra are possessed by the transition to $S_{2}$ state because $S_{1}$ state is just about forbidden $(14,15)$. Fluorescence is emitted from $S_{1}$ state, causing an extremely obvious Stokes shift because internal conversion from $S_{2}$ to $S_{1}$ is ultrafast (75-85 fs) $(16,17)$. Because of the low oscillator strength, $S_{1}$ lifetime is quite long which makes pyrene beneficial for non-radiant energy transfer (18). Conjugated pyrene derivatives are one of the significant organic functional intermediates as an organic semiconductor for application in photovoltaic devices such as OLEDs, OFETs, OLEFETs, and solar cells. For this purpose, studies were carried out to improve the electronic and optical properties of pyrene derivatives by changing their molecular structure by substituting electron donor or acceptor groups (19-22). Although many photoactive supramolecular systems containing two or more chromophores have been reported up to date, only a few articles about boron dipyrromethene-pyrene systems have been published (23-27).

In this contribution, we herein have designed and synthesized a solution processible D-A ח-conjugated small molecule which could be used as a semiconductor in the application of organic optoelectronics based on a BODIPY acceptor unit and pyrene donor unit that is linked via an alkyne spacer. The strategies designing the molecular structure were; $\pi$-donor pyrene unit substituted through the meso position of $\pi$-acceptor BODIPY unit for facilitating electron-transfer, methyl groups on BODIPY unit ensure good solubility in many organic solvents, so this solution processibility serves easy purification and thin film formation which is necessary for the semiconductor. The new semiconductor shows a large dipole moment calculated from the density functional theory program provides intramolecular charge transfer. The new molecule was characterized by mass spectrometry, FT-IR, ${ }^{1} \mathrm{H} /{ }^{13} \mathrm{C}$ NMR, elemental analysis, and thermogravimetric analysis (TGA). The optical and electrochemical properties of the new molecule were examined by UV-Vis absorption, fluorescence emission spectroscopies, and CV. Also, the photophysical and electrochemical properties of the molecule were studied by DFT program to calculate the photophysical and electrochemical parameters (28-30)

\section{EXPERIMENTAL SECTION}

\section{Materials and Equipments}

All reagents and solvents were bought through a trading agent and used as received unless mentioned. The reactions were done under argon gas unless otherwise noted. Analytical thin layer chromatography (TLC) for monitoring the reactions was used on silica gel plates (Merck, Kieselgel 60, $0.25 \mathrm{~mm}$ thickness) with an $\mathrm{F}_{254}$ indicator. Silica gel (Merck, Kieselgel 60, 230-400 mesh) was used in column chromatography. ${ }^{1} \mathrm{H}$ and ${ }^{13} \mathrm{C}$ NMR spectra were taken in $\mathrm{CDCl}_{3}$ solution on Varian INOVA 500
$\mathrm{MHz}$ spectrometer. Elemental analysis was performed using a Thermo Finnigan Flash 1112 Instrument. Mass spectra were recorded on a Bruker Daltonics Microflex LT MALDI-TOF mass spectrometer. Infrared spectra were measured on a Perkin Elmer Spectrum 100 Optica FT-IR Spectrometer. UV-Vis spectra were measured with a Shimadzu 2101 UV spectrophotometer. Fluorescence excitation and emission spectra were measured on a Varian Eclipse spectrofluorometer by using $1 \mathrm{~cm}$ path length cuvettes at $25^{\circ} \mathrm{C}$. Thermal properties of the compound were investigated on Mettler Toledo TGA/SDTA 851 TGA at a heating rate of $10{ }^{\circ} \mathrm{C} \mathrm{min}^{-1}$ under nitrogen flow. The electrochemical experiments were acquired using a $\mathrm{CHI} 842 \mathrm{~B}$ electrochemical workstation $(\mathrm{CH}$ Instruments).

\section{Electrochemical Calculations}

The electrochemical measurements were carried out by $\mathrm{CV}$ under argon at $25^{\circ} \mathrm{C}$ with a scanning rate of $100 \mathrm{mVs}^{-1}$. The experiments were performed in anhydrous dichloromethane with $0.1 \mathrm{M}$ tetrabutylammonium hexafluorophosphate $\left(\mathrm{TBAPF}_{6}\right)$ as an electrolyte. A standard three-electrode system in an electrochemical cell was used where a glassy carbon electrode served as the working electrode, a platinum wire electrode was the counter electrode, and an $\mathrm{Ag} / \mathrm{AgCl}$ (saturated $\mathrm{KCl}$ ) electrode was used as the reference electrode. The results are adjusted versus the $\mathrm{Fc} / \mathrm{Fc}^{+}$redox couple potential. The HOMO energy level of the compound was calculated from the onset oxidation potential $\left(E_{o x}\right)$ in $C V$, using the equation of $\mathrm{HOMO}=-\left[\mathrm{E}_{\mathrm{ox}}-\mathrm{E}_{1 / 2}\right.$ (ferrocene) +4.8$] \mathrm{V}$, where $E_{1 / 2}$ (ferrocene) is the onset oxidation potential of ferrocene vs. $\mathrm{Ag} / \mathrm{AgCl}$ reference electrode and 4.8 $\mathrm{eV}$ is the energy level of ferrocene below vacuum level. The LUMO energy level was calculated from the onset reduction potential in cyclic voltammetry, using the equation of LUMO $=-\left[E_{\text {red }}-E_{1 / 2}\right.$ (ferrocene)+ 4.8] V. The band gap $\left(E_{g}\right)$ was calculated using the equation of $E_{g}=E_{\text {LUMO- }}-E_{\text {Hомо }}$

\section{Synthesis}

The necessary compound $\mathbf{1}, \mathbf{2}$ and $\mathbf{3}$ for the successful preparation of novel Py-BODIPY $\mathbf{4}$ were synthesized and characterized according to literature procedure $(31,32)$.

\section{Synthesis} ylethynyl)silane (1)

1-Bromopyrene (100 mg, $3.6 \mathrm{mmol}$ ) was added to triethylamine $\left(\mathrm{Et}_{3} \mathrm{~N}\right)(40 \mathrm{~mL})$ and toluene $(6 \mathrm{~mL})$ and then, tetrakis(triphenylphosphine)palladium(0) $\left(\mathrm{Pd}\left(\mathrm{PPh}_{3}\right)_{4}\right)(210 \mathrm{mg}, 0.18 \mathrm{mmol})$, copper(I)iodide (69 $\mathrm{mg}, 0.36 \mathrm{mmol})$, triphenylphosphine $\left(\mathrm{PPh}_{3}\right)(94 \mathrm{mg}$, $0.36 \mathrm{mmol}$ ) were added under argon atmosphere, respectively. Then the reaction mixture was heated to $60{ }^{\circ} \mathrm{C}$ and trimethylsilylacetylene (TMSA) (700 $\mathrm{mg}, 7.2 \mathrm{mmol}$ ) was injected through a septum. After $15 \mathrm{~min}$ the reaction was heated to $80^{\circ} \mathrm{C}$ and stirred overnight. The cooled reaction mixture was extracted with dichloromethane and water. The 
collected organic phase was dried over $\mathrm{Na}_{2} \mathrm{SO}_{4}$, and the solvent was evaporated under reduced pressure. The residue was purified by column chromatography, and petroleum ether was used as the eluent. ${ }^{1} \mathrm{H}$ NMR (in $\left.\mathrm{CDCl}_{3}\right) \delta(\mathrm{ppm})=8.58(\mathrm{~d}, 1 \mathrm{H}$, $J=8.5 \mathrm{~Hz}), 8.16-8.02(\mathrm{~m}, 8 \mathrm{H}), 0.43(\mathrm{~s}, 9 \mathrm{H})$. MS (MALDI-TOF) $\quad\left(\mathrm{C}_{21} \mathrm{H}_{18} \mathrm{Si}\right) \mathrm{m} / \mathrm{z}$ : Calc. 298.12, found $299.067[\mathrm{M}+\mathrm{H}]^{+}$.

\section{Synthesis of 1-ethynylpyrene (2)}

Compound 1 ( $370 \mathrm{mg}, 1.2 \mathrm{mmol}$ ) was suspended in methanol $(25 \mathrm{~mL}) . \mathrm{K}_{2} \mathrm{CO}_{3}(330 \mathrm{mg}, 2.4 \mathrm{mmol})$ was added and the reaction mixture stirred at room temperature (rt) overnight and then poured into water $(100 \mathrm{~mL})$ and filtered. The filter was washed with water until the filtrate was neutral. Compound 2 was obtained as a brown solid $(230 \mathrm{mg}, 85 \%) .{ }^{1} \mathrm{H}$ NMR (in $\mathrm{CDCl}_{3}$ ) $\delta(\mathrm{ppm})=8.60(\mathrm{~d}, 1 \mathrm{H}, J=8.8 \mathrm{~Hz}$ ), 8.25-8.02 (m, 8H), $3.63(\mathrm{~s}, 1 \mathrm{H})$. MS (MALDI-TOF) $\left(\mathrm{C}_{18} \mathrm{H}_{10}\right) \mathrm{m} / \mathrm{z}$ : Calc. 226.08, found 226.089 [M] ${ }^{+}$.

\section{Synthesis of 1,3,5,7-tetramethyl-8-(4- bromophenyl)-4,4-difluoro-4-bora-3a,4a-diaza- s-indacene (3)}

4-Bromobenzaldehyde (1.0 g, $5.4 \mathrm{mmol}), 2,4$ dimethylpyrrole $(1.0 \mathrm{~g}, 10.5 \mathrm{mmol})$ and trifluoroacetic acid (TFA) $(16 \mu \mathrm{L}, 0.2 \mathrm{mmol})$ were dissolved in dry dichloromethane $(250 \mathrm{~mL})$ under argon, and the reaction mixture was stirred at rt for 18h. The disappearance of the benzaldehyde was controlled via TLC and then a solution of 2,3dichloro-5,6-dicyano-1,4-benzoquinone (DDQ) (1.2 $\mathrm{g}, 5.3 \mathrm{mmol})$ in dry tetrahydrofuran (THF) $(20 \mathrm{~mL})$ was added slowly to the reaction mixture and stirred for an additional $4 \mathrm{~h}$. The mixture was then cooled to $0{ }^{\circ} \mathrm{C}, \mathrm{Et}_{3} \mathrm{~N}(16 \mathrm{~mL}$ ) was added, and then the mixture was warmed to rt. After stirring for $2 \mathrm{~h}$, boron trifluoride diethyl etherate $\left(\mathrm{BF}_{3} . \mathrm{OEt}_{2}\right)(16 \mathrm{~mL})$ was added, and the reaction mixture stirred for an additional $18 \mathrm{~h}$ at $\mathrm{rt}$. A saturated sodium bicarbonate solution $(200 \mathrm{~mL})$ was then added to the mixture. The organic layer was separated and concentrated under reduced pressure to approximately $50 \mathrm{~mL}$ followed by the addition of 200 $\mathrm{mL}$ water. The mixture was extracted with diethyl ether ( 3 times of $200 \mathrm{~mL}$ ), the collected organic extracts were dried over anhydrous $\mathrm{Na}_{2} \mathrm{SO}_{4}$ and the solvent was evaporated under reduced pressure. The raw product was purified by flash column chromatography on silica gel eluting with dichloromethane/n-hexane $(1: 1)$ to obtain the product as a dark-orange solid (101 $\mathrm{mg}, 25 \%$ yield). ${ }^{1} \mathrm{H}$ NMR (in $\mathrm{CDCl}_{3}$ ) $\delta(\mathrm{ppm})=7.63(\mathrm{~d}, 2 \mathrm{H}, J=8.0 \mathrm{~Hz}$ ) $7.20(\mathrm{~d}, 2 \mathrm{H}, J=8.0 \mathrm{~Hz}), 5.94(\mathrm{~s}, 2 \mathrm{H}), 2.52(\mathrm{~s}, 6 \mathrm{H})$, $1.45(\mathrm{~s}, 6 \mathrm{H})$; MS (MALDI-TOF) $\left(\mathrm{C}_{19} \mathrm{H}_{18} \mathrm{BF}_{2} \mathrm{~N}_{2} \mathrm{Br}\right) \mathrm{m} / \mathrm{z}$ : Calc. 402.071, found 403.064 $[\mathrm{M}+\mathrm{H}]^{+}$.

\section{Synthesis of 1,3,5,7-tetramethyl-8-(4-(pyren- 1-ylethynyl)phenyl)-4,4-difluoro-4-bora-3a,4a- diaza-s-indacene (4)}

Compound 3 (100 mg, $0.25 \mathrm{mmol}$ ) was dissolved in $\mathrm{Et}_{3} \mathrm{~N}(1.2 \mathrm{~mL})$ and it was bubbled with argon for 15 min. Later on, bis(triphenylphosphine)palladium dichloride $\left(\mathrm{Pd}\left(\mathrm{PPh}_{3}\right)_{2} \mathrm{Cl}_{2}\right)$ (5.26 $\left.\mathrm{mg}, 0.0075 \mathrm{mmol}\right)$, Cul (3.09 mg, $0.016 \mathrm{mmol}), \mathrm{PPh}_{3}(3.3 \mathrm{mg}, 0.013$ $\mathrm{mmol})$, and 1-ethynylpyrene (2) $(57 \mathrm{mg}, 0.25 \mathrm{mmol})$ were added to the solution under argon. The reacted product was heated to $60{ }^{\circ} \mathrm{C}$ and stirred for $24 \mathrm{~h}$. It was cooled to rt and concentrated under reduced pressure. The pure product was obtained as a reddish solid (27 $\mathrm{mg}, 20 \%$ yield) after silicagel-filled column chromatography with using n-hexane/dichloromethane (10:1) solvent system. ${ }^{1} \mathrm{H}$ NMR (in $\left.\mathrm{CDCl}_{3}\right) \delta(\mathrm{ppm})=8.70(\mathrm{~d}, 1 \mathrm{H}, J=8.6 \mathrm{~Hz})$, 8.27-8.23(m, $4 \mathrm{H}), 8.15(\mathrm{dd}, 2 \mathrm{H}, J=16.1 \mathrm{~Hz}, J=8.3$ $\mathrm{Hz}), 8.07(\mathrm{~m}, 2 \mathrm{H}), 7.86(\mathrm{~d}, 2 \mathrm{H}, \mathrm{J}=8.2 \mathrm{~Hz}), 7.38(\mathrm{~d}$, $2 \mathrm{H}, J=7.4 \mathrm{~Hz}), 6.02(\mathrm{~s}, 2 \mathrm{H}), 2.58(\mathrm{~s}, 6 \mathrm{H}), 1.51(\mathrm{~s}, 6 \mathrm{H})$; ${ }^{13} \mathrm{C} \mathrm{NMR} \mathrm{(in} \mathrm{CDCl}_{3}$ ) $\delta(\mathrm{ppm})=157.52,155.72$, $150.73,142.85,141.73,138.53,137.12,135.44$, $135.10,131.72,131.11,129.77,129.59,129.33$, $128.95,128.64,128.25,127.69,126.68,125.25$, $119.20,116,25,110.25,87.96,87.10,15.88,14.89$. Elemental analysis: Calc. for $\mathrm{C}_{37} \mathrm{H}_{27} \mathrm{BF}_{2} \mathrm{~N}_{2}$ : C, 81.03; $\mathrm{H}, 4.96$; N, 5.11. Found: $\mathrm{C}, 80.79 ; \mathrm{H}, 5.13 ; \mathrm{N}, 5.18 \%$. MS (MALDI-TOF) m/z: Calc. 548.44, found 548.74 [M] $+$

\section{RESULTS AND DISCUSSION}

The synthetic route for the synthesis of $\mathbf{4}$ was outlined in Scheme 1. The intermediates (1, 2, and 3) which were used in the synthesis of the target compound were carried out according to the literature procedures. Briefly, 1 was obtained from a Sonogashira cross-coupling reaction of 1bromopyrene and TMSA, using palladium precatalyst and copper co-catalyst system, following this reaction trimethylsilyl group of $\mathbf{1}$ was eliminated with $\mathrm{K}_{2} \mathrm{CO}_{3}$ in methanol, and $\mathbf{2}$ was obtained in high yield of $85 \%$. On the other hand, $\mathbf{3}$ was prepared by sequential reactions. For this purpose first, the condensation reaction of 2,4-dimethylpyrrole with 4bromobenzaldehyde in the presence of TFA was performed to obtain dipyrromethane, then it was oxidized with DDQ and then coordinated with $\mathrm{BF}_{3} . \mathrm{OEt}_{2}$ using $\mathrm{Et}_{3} \mathrm{~N}$ as the base to afford $\mathbf{3}$ intermediate. Conjugated pyrene-BODIPY target compound 4 was obtained by the Sonogashira reaction in the presence of $\mathrm{Pd}\left(\mathrm{PPh}_{3}\right)_{2} \mathrm{Cl}_{2} / \mathrm{Cul}$ catalyst system and $\mathrm{Et}_{3} \mathrm{~N}$ (acted as base and solvent) of the prepared intermediates. Encouragingly, the good solubility of the target compound in many organic solvents helped easy purification and analysis of pyrene-BODIPY 4. Despite of good solubility the pure compound 4 was obtained in $20 \%$ yield only. 


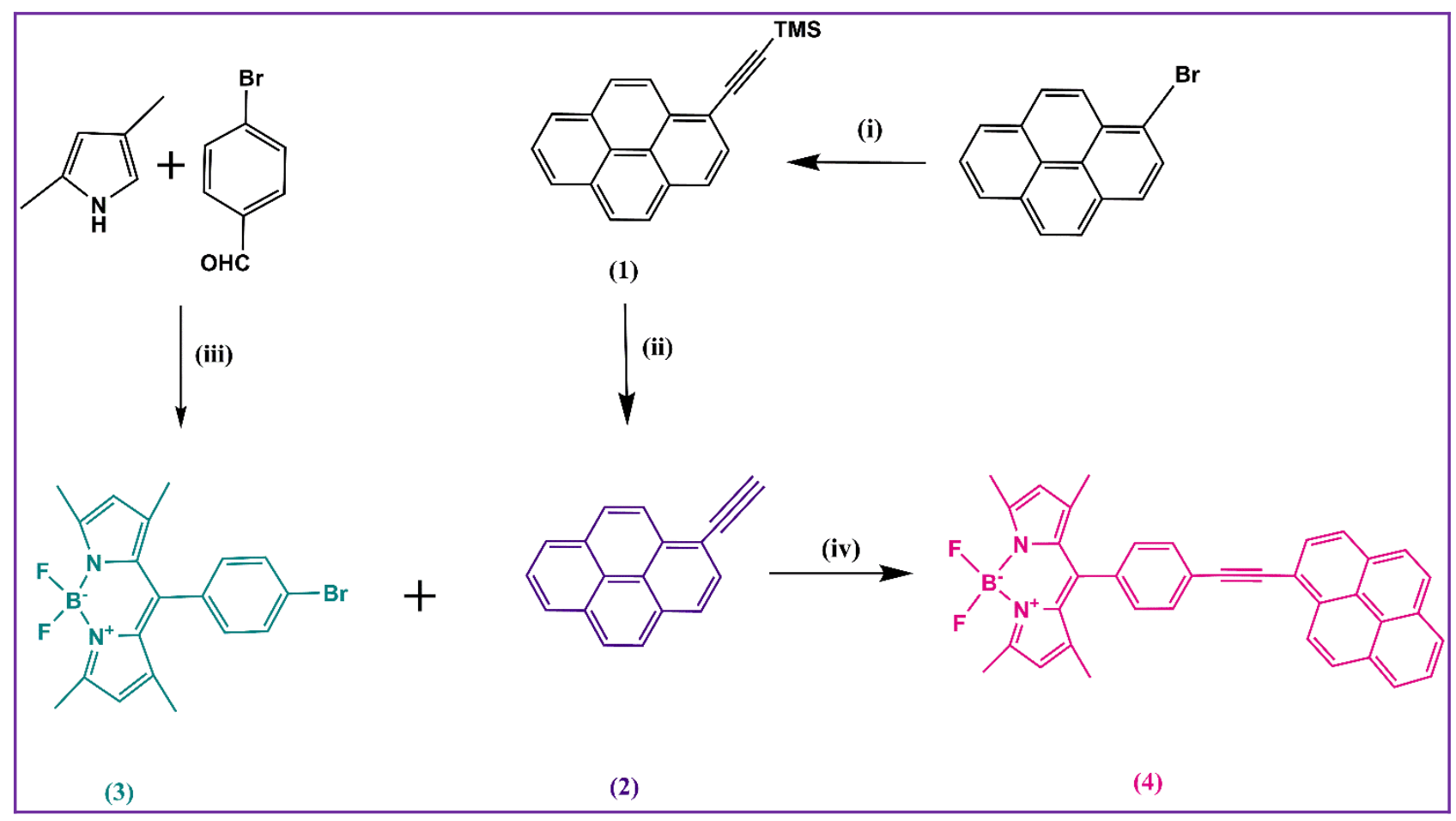

Scheme 1: The synthetic route to compound 4. (i) TMSA, $\mathrm{Et}_{3} \mathrm{~N}$, Toluene, Cul, $\mathrm{Pd}\left(\mathrm{PPh}_{3}\right)_{4}, \mathrm{PPh}_{3} ;$ (ii) $\mathrm{K}_{2} \mathrm{CO}_{3}$, $\mathrm{MeOH}$; (iii) TFA, THF, DDQ, $\mathrm{Et}_{3} \mathrm{~N}, \mathrm{BF}_{3} . \mathrm{OEt}_{2}$; (iv) $\mathrm{Et}_{3} \mathrm{~N}, \mathrm{Cul}, \mathrm{Pd}_{2}\left(\mathrm{PPh}_{3}\right)_{2} \mathrm{Cl}_{2}, \mathrm{PPh}_{3}$.

The structures of the molecules were determined with general spectroscopic methods, such as mass spectrometry, NMR spectroscopy, FT-IR spectra, and elemental analysis. The results received were matched with the expected structures as seen in the experimental part. In Figure 1 , the molecular ion peak of the target compound was seen at $\mathrm{m} / \mathrm{z} 548$, additional peak which was seen at $\mathrm{m} / \mathrm{z} 529$ was attributed to the separation of fluorine, which is common in BODIPY compounds (33). The characteristic carbon-carbon triple bond and acetyl$\mathrm{CH}$ stretch bands of the acetylene group were seen at 3292 and $2100 \mathrm{~cm}^{-1}$ on FT-IR spectra of EthyPy compound. However, the disappearance of the band at $3292 \mathrm{~cm}^{-1}$ while the band at $2100 \mathrm{~cm}^{-1}$ only shifted to $2200 \mathrm{~cm}^{-1}$, confirmed the structure of $\mathbf{4}$ (Figure 3 ). The ${ }^{1} \mathrm{H}$ NMR spectra of $\mathbf{4}$ is shown in Figure 2. The pyrene protons were located in the region of $\delta=8.22-8.71 \mathrm{ppm}$, and the phenyl protons were shown at 7.86 and 7.38 as two sets of a doublet. The proton signals of two $\mathrm{CH}$-groups and the four $\mathrm{CH}_{3}$-groups on the pyrrole ring were monitored at $\delta=6.02 \mathrm{ppm}$ and $\delta=2.58,1.51 \mathrm{ppm}$, respectively.

The thermal behavior of the compound $\mathbf{4}$ was carried out using TGA. The decomposition temperature ( $\mathrm{Td}$ ) of the compound was estimated in the temperature scale from $25{ }^{\circ} \mathrm{C}$ to $700{ }^{\circ} \mathrm{C}$ at a heating rate of $10^{\circ} \mathrm{C} / \mathrm{min}$ and TGA observed that the compound has good stability in nitrogen, with the $5 \%$ of $\mathrm{Td}$ of $227^{\circ} \mathrm{C}$. Remained char yield was $52 \%$ at $700{ }^{\circ} \mathrm{C}$ (Figure 4).

As shown in Figure $5 a$, UV-Vis absorption and normalized fluorescence emission spectra of dye $\mathbf{4}$ and its sub-units $\mathbf{2}$ and $\mathbf{3}$ chromophores were measured at rt in dichloromethane for comparison. $\mathbf{2}$ and $\mathbf{3}$ exhibit absorption maxima at 358 and 502 $\mathrm{nm}$ which were attributed $\pi-\pi^{*}$ transitions of pyrene and BODIPY moieties, respectively $(31,34)$. The dye 4 exhibits a strong absorption peak at a low energy band $(502 \mathrm{~nm})$ which is appointed to the $\mathrm{S}_{0}-\mathrm{S}_{1}$ transition of BODIPY unit and, the broad absorption peak at high energy band region (347- $384 \mathrm{~nm}$ ) is appointed to $S_{0}-S_{2}$ transitions of the pyrene unit and also $\mathrm{S}_{0}-\mathrm{S}_{1}$ transition of BODIPY unit, which are consistent with previously reported pyrene and BODIPY chromophores (35-39). The optical energy gap width $\left(E_{g}^{\text {opt }}\right)$ obtained from the absorption spectra in solution is $2.43 \mathrm{eV}$ which consistent with the experimental result from the CV. 


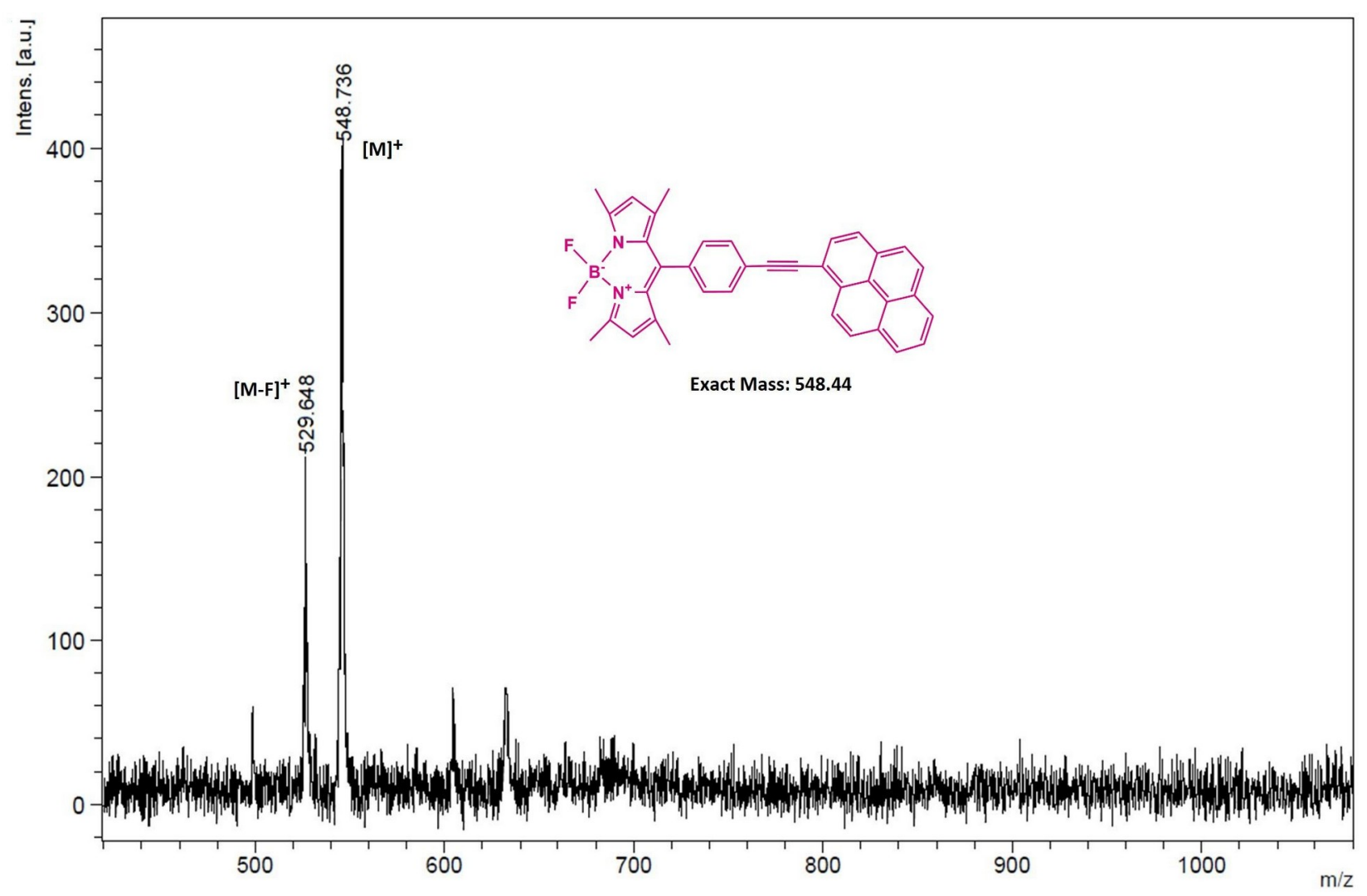

Figure 1: MALDI-MS spectra of 4.

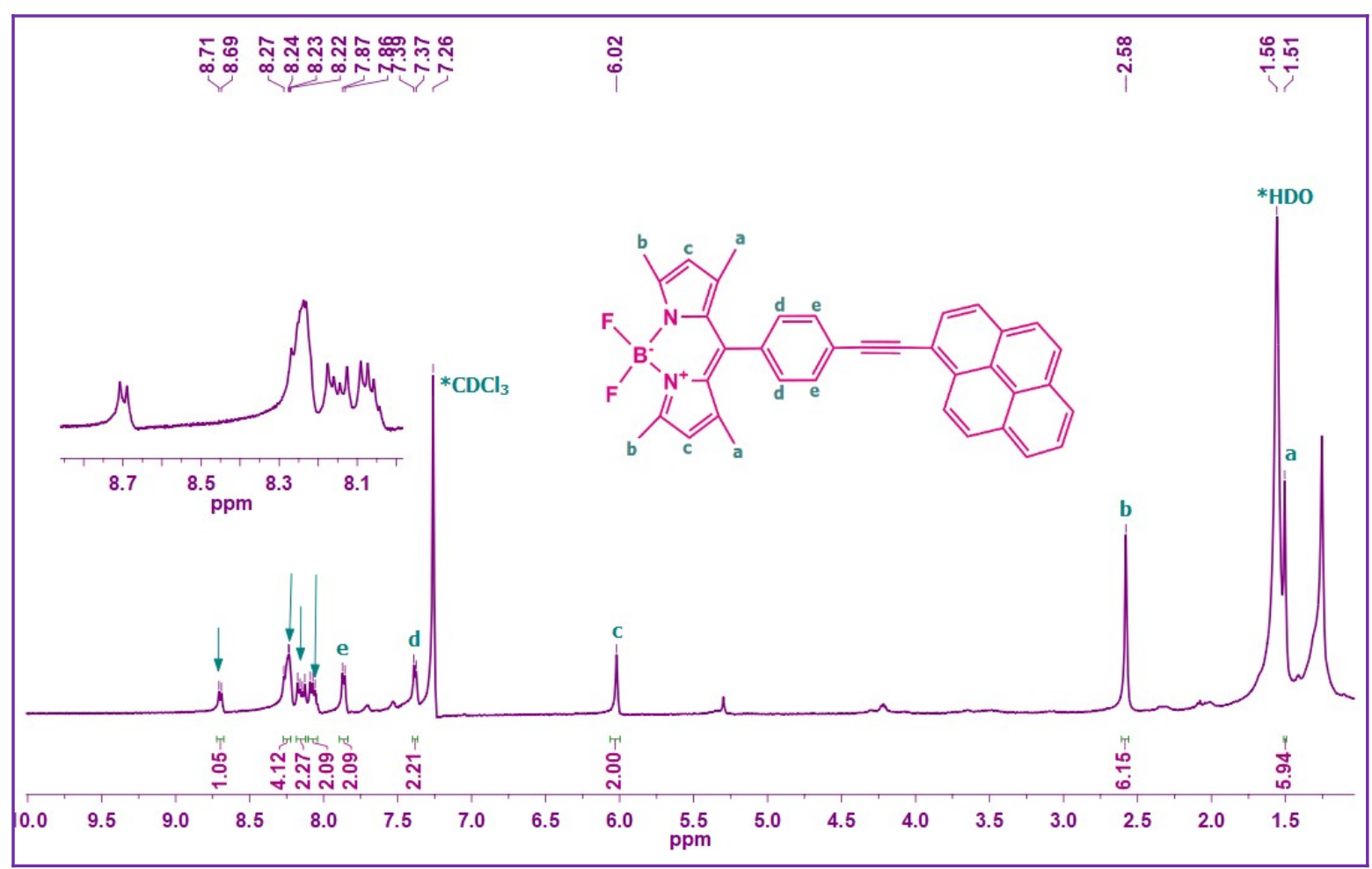

Figure 2: ${ }^{1} \mathrm{H}$ NMR spectra of 4 in $\mathrm{CDCl}_{3}$. 


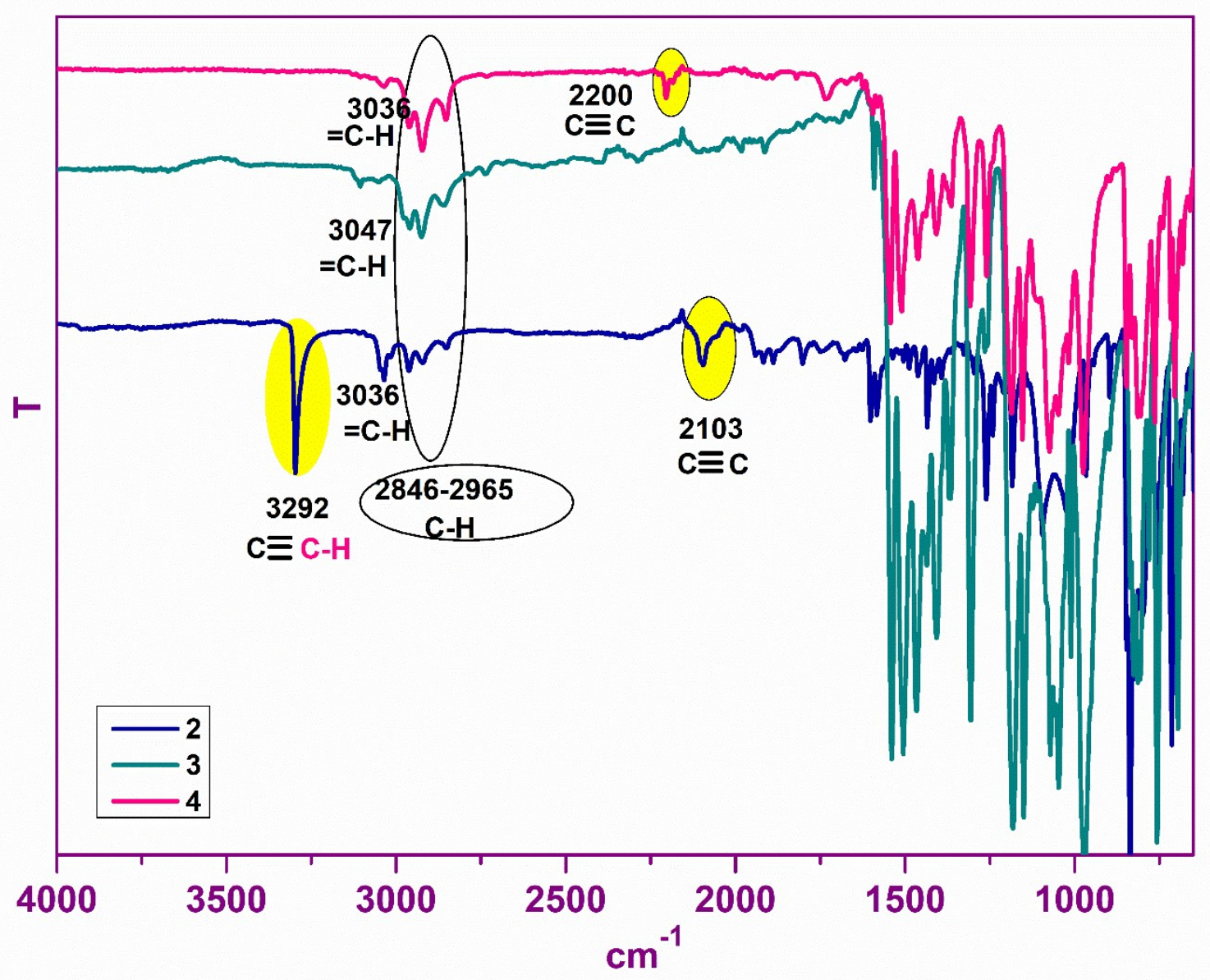

Figure 3: FT-IR spectra of 2, 3, and 4.

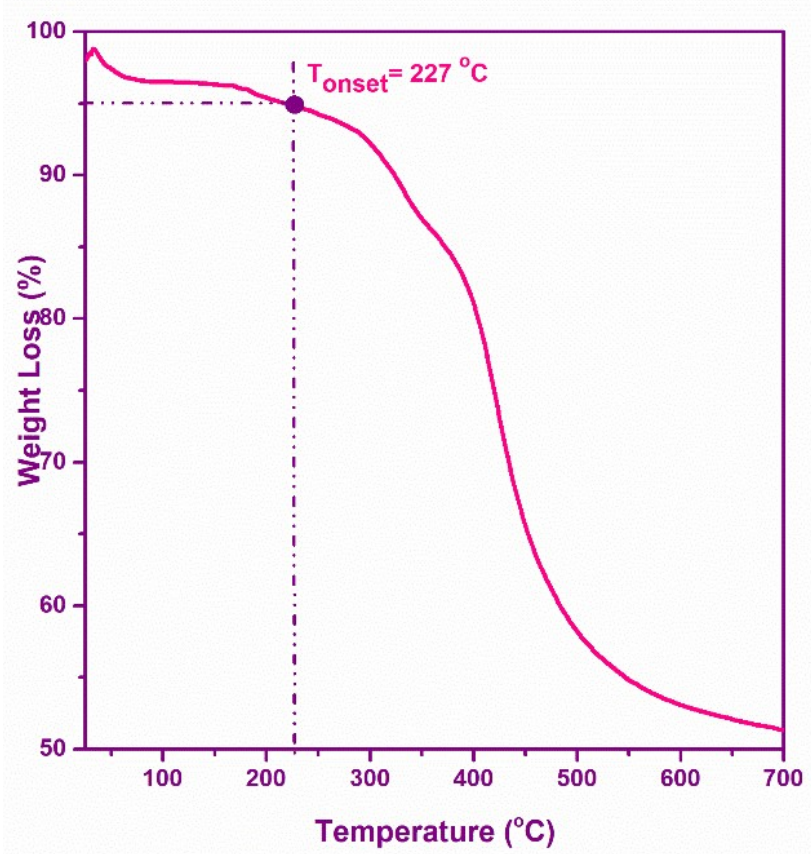

Figure 4: TGA thermogram of 4 at a temperature ramp of $10{ }^{\circ} \mathrm{C} /$ min under $\mathrm{N}_{2}$. 
Fluorescence emission spectra for all compounds obtained upon excitation at $350 \mathrm{~nm}$ for comparison. The emission spectra of compounds show good mirror symmetry with the corresponding absorption bands except one that corresponds to pyrene on BODIPY unit is at the range of $350-390 \mathrm{~nm}$ are no longer present. (Figure 6a). Also, the lifetime of the compounds was studied at $310 \mathrm{~nm}$ excitation and observed 16 ns for $\mathbf{2}, 2.78$ ns for $\mathbf{3}$ and, 1.78 ns for 4 (Figure 6b).

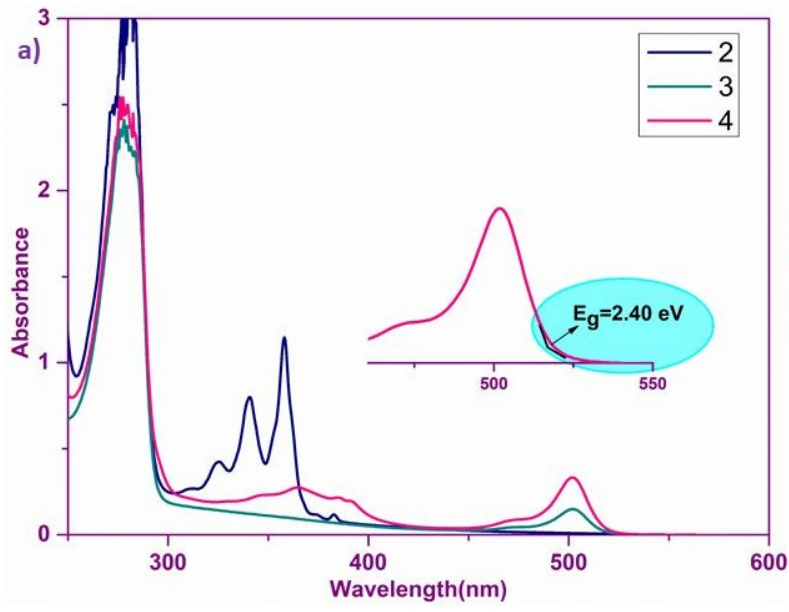

Cyclic voltammetry in dichloromethane solution demonstrates a reversible reduction for $\mathbf{4}$ with the half-wave potential $\left(E_{1 / 2}\right.$ red) located at $-1.13 \mathrm{~V}$ (vs $\mathrm{Ag} / \mathrm{AgCl}$ ). This shows a high LUMO energy level of $3.27 \mathrm{eV}$ for 4 shows reversible oxidation for $\mathbf{4}$ with the half-wave potential $\left(E_{1 / 2}\right.$ ox) located at $1.30 \mathrm{~V}$ ( $v s$ $\mathrm{Ag} / \mathrm{AgCl}$ ) and the HOMO energy level of $-5.70 \mathrm{eV}$ for 4 (Figure $5 b$ )

Figure 5: a) Optical absorption spectra of 4 in dichloromethane solution, and the corresponding optical band gap $\left(E_{g}\right)$. b) Cyclic voltammogram of 4 in dichloromethane $\left(0.1 \mathrm{M} \mathrm{Bu}_{4} \mathrm{~N}^{+} \mathrm{PF}_{6}^{-}\right.$, scan rate $\left.=100 \mathrm{mV} / \mathrm{s}\right)$ and experimental HOMO-LUMO energy levels.
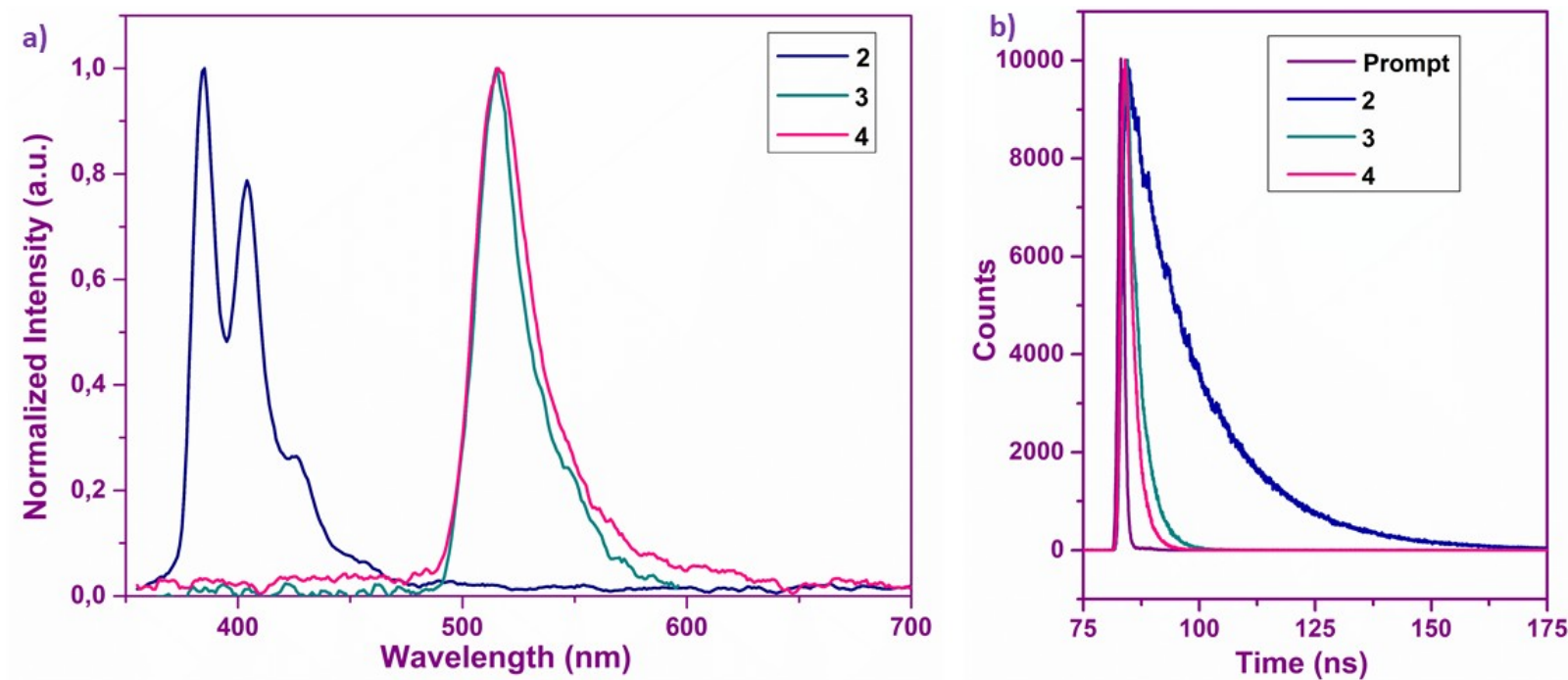

Figure 6: a) Fluorescence spectra b) Lifetime spectra of compounds (2, 3, and 4).

To understand more about the structural and electronic properties of the compound 4, DFT analysis was performed at the B3LYP/6-31G* basis set. DFT calculations show that the phenyl ring is orthogonal to the BODIPY ring plane at a $90^{\circ}$ dihedral angle. The reason is thought to be due to the steric impediment of methyl groups located at $\beta$ positions of pyrrole unit, so this impediment

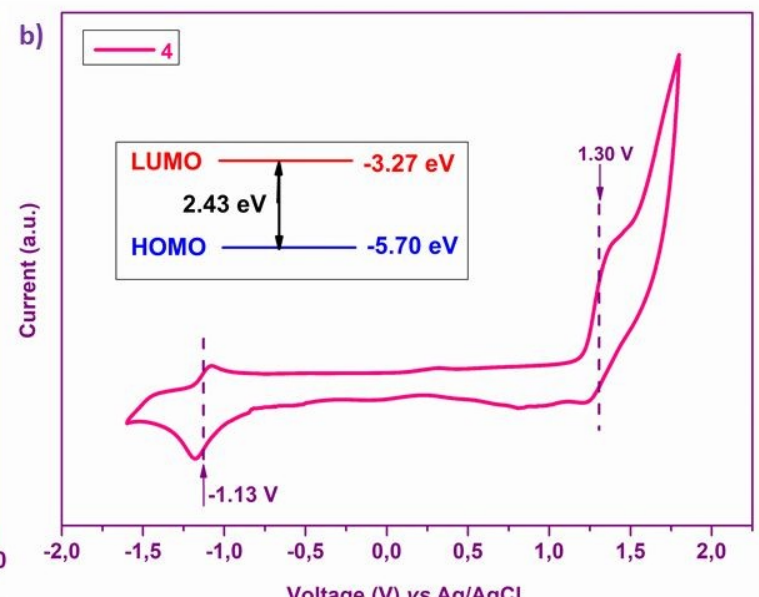

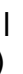



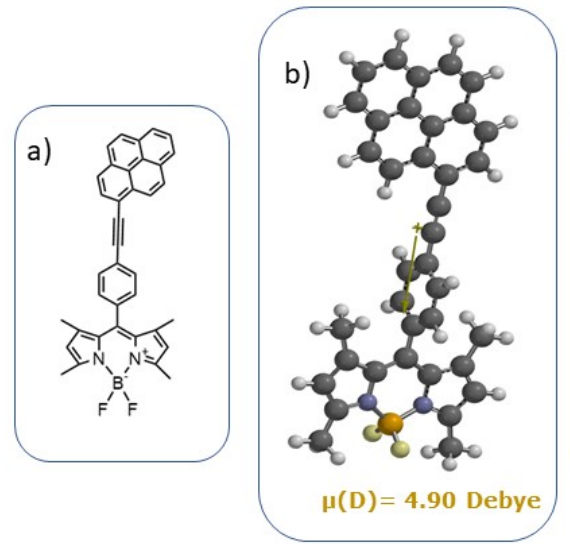
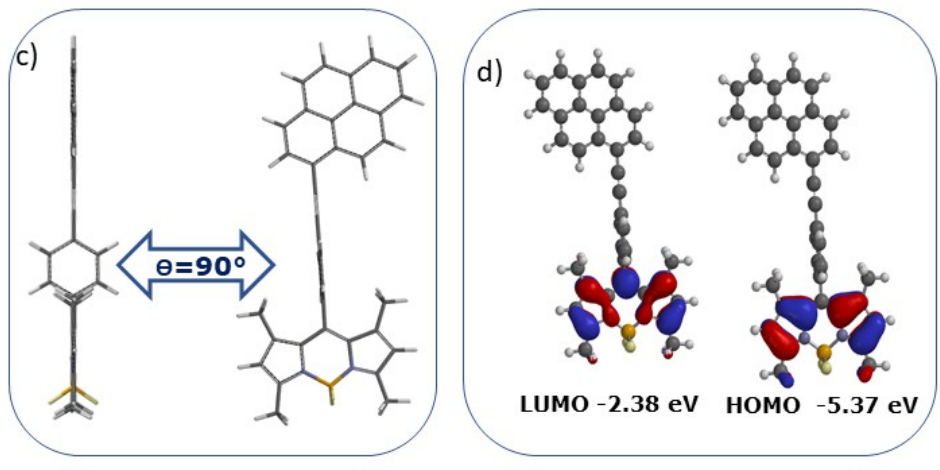

Figure 7: a) Molecular structure of compound 4, b) Optimal geometry along with calculated dipole moment, c) Optimized molecular geometry showing inter-ring dihedral angle, d) DFT calculated frontier molecular orbital (HOMO and LUMO energy levels).

\section{CONCLUSION}

A new conjugated BODIPY dyad 4 consisting of pyrene as a donor group and BODIPY as an acceptor group linked via ethyne spacer was designed, synthesized, and successfully characterized. For a better understanding of its molecular nature, energy levels (HOMO/LUMO), and optical/electrochemical features were also examined by theoretical calculations, absorption and emission spectroscopies, and cyclic voltammetry. Based on all the studies, it can be concluded that the newly synthesized pyrene-BODIPY, a molecule having a relatively low band gap, could be of promising interest in future OLEDs.

\section{ACKNOWLEDGMENTS}

It is our pleasure to present this study consisting of selected papers based on poster presentations from the 2020 meeting of the $32^{\text {nd }}$ National Chemistry Congress held on September 17-19 by Turkish Chemical Society, Turkey.

\section{REFERENCES}

1. Ward MD. Photo-induced electron and energy transfer in non-covalently bonded supramolecular assemblies. Chemical Society Reviews. 1997; 26:365-75.

2. Balzani V, Bergamini G, Ceroni P. From the photochemistry of coordination compounds to lightpowered nanoscale devices and machines. Coordination Chemistry Reviews. 2008; 252:245669.

3. Guldi DM. Fullerene-porphyrin architectures; photosynthetic antenna and reaction center models. Chemical Society Reviews. 2002; 31:22-36.
4. Haugland RP. Handbook of Fluorescent Probes and Research Chemicals, 10th ed.; Molecular Probes: Eugene, OR, 2005.

5. Thoresen LH, Kim H, Welch MB, Burghart $A$, Burgess K. Synthesis of 3,5-diaryl-4,4-difluro-4-bora3a,4a-diaza-s-indacene (BODIPY) dyes. Synlett. 1998; 1276-1278.

6. Rurack K, Kollmannsberger M, Daub J. A highly efficient sensor molecule emitting in the near infrared (NIR): 3,5-distyryl-8-(pdimethylaminophenyl)difluoroboradiaza-s-indacene. New Journal of Chemistry. 2001; 25: 289-292.

7. Loudet A, Burgess K. BODIPY Dyes and Their Derivatives: Syntheses and Spectroscopic Properties. Chemical Reviews. 2007; 107:48914932.

8. Ulrich G, Ziessel R, Harriman A. The Chemistry of Fluorescent Bodipy Dyes: Versatility Unsurpassed. Angewandte Chemie International Edition. 2008; 47: 1184-201.

9. Kowada T, Maeda H, Kikuchi K. BODIPY-based probes for the fluorescence imaging of biomolecules in living cells. Chemical Society Reviews. 2015; 44: 4953-972.

10. Ho D, Ozdemir R, Kim H, Earmme T, Usta H, Kim C. BODIPY-Based Semiconducting Materials for Organic Bulk Heterojunction Photovoltaics and ThinFilm Transistors. ChemPlusChem. 2019; 84: 18-37.

11. Winnik FM. Photophysics of preassociated pyrenes in aqueous polymer solutions and in other organized media. Chemical Reviews. 1993; 93:587614.

12. Duhamel J. New insights in the study of pyrene excimer fluorescence to characterize 
macromolecules and their supramolecular assemblies in solution. Langmuir. 2012; 28:6527-38.

13. Yeşilot S, Çoşut B, Ardıç Alidağı H, Hacıvelioğlu F, Altınbaş Özpınar G, Kılıç A. Intramolecular excimer formation in

hexakis-

(pyrenyloxy)cyclotriphosphazene: photophysical properties, crystal structure, and theoretical investigation. Dalton Transaction. 2014; 43: 342833.

14. Lambert C, Ehbets J, Rausch D, Steeger M. Charge-Transfer Interactions in a Multichromophoric Hexaarylbenzene Containing Pyrene and Triarylamines. Journal of Organic Chemistry. 2012; 77: 6147-54.

15. Merz J, Fink J, Friedrich A, Krummenacher I, Al Mamari $\mathrm{HH}$, Lorenzen $\mathrm{S}$, Haehnel $M$, Eichhorn $A$, Moos M, Holzapfel $M$, Braunschweig $H$, Lambert $C$, Steffen A, Ji L, Marder TB. Pyrene Molecular Orbital Shuffle-Controlling Excited State and Redox Properties by Changing the Nature of the Frontier Orbitals. Chemistry Europian Journal. 2017; 23:13164-80.

16. Raytchev M, Pandurski E, Buchvarov I, Modrakowski C, Fiebig T. Bichromophoric Interactions and Time-Dependent Excited State Mixing in Pyrene Derivatives. A Femtosecond BroadBand Pump-Probe Study. Journal of Physical Chemistry A. 2003; 107: 4592-600.

17. Krebs N, Pugliesi I, Hauer J, Riedle E. Twodimensional Fourier transform spectroscopy in the ultraviolet with sub-20 fs pump pulses and 250-720 $\mathrm{nm}$ supercontinuum probe. New Journal of Physics. 2013; 15: 085016.

18. Rodriguez-Cordoba W, Sierra CA, Puentes CO, Lahti PM, Peon J. Photoinduced energy transfer in bichromophoric pyrene-PPV oligomer systems: the role of flexible donor-acceptor bridges. Journal of Physical Chemistry B. 2012; 116: 3490-503.

19. Lee OP, Yiu AT, Beaujuge PM, Woo CH, Holcombe TW, Millstone JE, Douglas JD, Chen MS, Frechet JMJ. Efficient small molecule bulk heterojunction solar cells with high fill factors via pyrene-directed molecular self-assembly. Advanced Materials. 2011; 23: 5359-63.

20. Oniwa $\mathrm{K}$, Kikuchi $\mathrm{H}$, Shimotani $\mathrm{H}$, Ikeda $\mathrm{S}$, Asao $\mathrm{N}$, Yamamoto $\mathrm{Y}$, Tanigaki K, Jin T. 2-Positional pyrene end-capped oligothiophenes for high performance organic field effect transistors. Chemical Communications. 2016; 52: 4800-03.

21. Ardıç Alidağı H, Cosut B, Kılıc A, Yesilot S. Synthesis and spectral properties of a hexameric pyrene-fluorene chromophore based on cyclotriphosphazene. Polyhedron. 2014; 81: 436-41.
22. Figueira-Duarte TM, Mullen K. Pyrene-based materials for organic electronics. Chemical Reviews. 2011; 111: 7260-314.

23. Callaghan S, Filatov MA, Savoie H, Boyle RW, Senge MO. In vitro cytotoxicity of a library of BODIPYanthracene and -pyrene dyads for application in photodynamic therapy. Photochemical \& Photobiological Sciences. 2019; 18: 495-504.

24. Ziessel R, Goze C, Ulrich G, Cesario M, Retailleau $P$, Harriman A, Rostron JP. Intramolecular energy transfer in pyrene-BODIPY molecular dyads and triads. Chemistry A Europian Journal. 2005; 11: 7366-78.

25. Yang Y, Zhang L, Gao C, Xu L, Bai S, Liu X. Pyrene-based BODIPY: synthesis, photophysics and lasing properties under UV-pumping radiation. RSC Advances. 2014; 4: 38119-23.

26. Fakis $M$, Beckwith JS, Seintis $K$, Martinou $E$, Nançoz C, Karakostas N, Petsalakis I, Pistolis G, Vauthey E. Energy transfer and charge separation Dynamics in photoexcited pyrene-bodipy molecular dyads. Physical Chemistry Chemical Physics. 2018; 20: 837-49.

27. Porcu P, Vonlanthen M, González-Méndez I, Ruiu A, Rivera E. Design of Novel Pyrene-Bodipy Dyads: Synthesis, Characterization, Optical Properties, and FRET Studies. Molecules. 2018; 23: 2289.

28. Matin MM, Chakraborty $P$, Alam MS, Islam MM, Hanee U. Novel mannopyranoside esters as sterol $14 \alpha$ - demethylase inhibitors: Synthesis, PASS predication, molecular docking, and pharmacokinetic studies. Carbohydrate Research. 2020; 496: 108130.

29. Özkınalı S, Çavuş MS, Sakin B. Synthesis, Characterisation and DFT Calculations of Azo-Imine Dyes. Journal of the Turkish Chemical Society Section A: Chemistry. 2018; 5(1): 159-78.

30. Matin MM, Bhattacharjee SC, Chakraborty $P$, Alam MS. Synthesis, PASS predication, in vitro antimicrobial evaluation and pharmacokinetic study of novel n-octyl glucopyranoside esters. Carbohydrate Research. 2019; 485: 107812.

31. Bernhardt $\mathrm{S}$, Kastler $\mathrm{M}$, Enkelmann $\mathrm{V}$, Baumgarten $M$, and Müllen $K$. Pyrene as Chromophore and Electrophore: Encapsulation in a Rigid Polyphenylene Shell. Chemistry A Europian Journal. 2006; 12: 6117 - 28.

32. Sun J, Zhong $F$, Yi $X$, Zhao J. Efficient Enhancement of the Visible-Light Absorption of Cyclometalated Ir(III) Complexes Triplet Photosensitizers with Bodipy and Applications in Photooxidation and Triplet-Triplet Annihilation 
Upconversion. Inorganic Chemistry. 2013; 52: 6299-6310.

33. Çetindere $S$, Tümay SO, Şenocak $A$, Kılıç $A$, Durmuş $M$, Demirbaş $E$, Yeşilot $S$. Novel pyreneBODIPY dyes based on cyclotriphosphazene scaffolds: Synthesis, photophysical and spectroelectrochemical properties. Inorganica Chimica Acta. 2019; 494: 132-40.

34. Cosut B. Highly efficient energy transfer in BODIPY-pyrene decorated cyclotriphosphazene. Dyes and Pigments. 2014; 100:11-16.

35. Cetindere S. Photophysics of BODIPY Dyes: Recent Advances. Intech Open. Chapter, 2020.

36. Mahapatra AK, Maji R, Maiti K, Manna SK, Mondal S, Ali SS, Manna S, Sahoo P, Mandal S, Uddin MR, Mandal D. A BODIPY/pyrene-based chemodosimetric fluorescent chemosensor for selective sensing of hydrazine in the gas and aqueous solution state and its imaging in living cells. RSC Advances. 2015; 5: 58228-36.

37. Karolin J, Johansson LBA, Strandberg L, Ny T. Fluorescence and Absorption Spectroscopic Properties of Dipyrrometheneboron Difluoride (BODIPY) Derivatives in Liquids, Lipid Membranes, and Proteins. Journal of American Chemical Society. 1994; 116: 7801-6.
38. Toele P, Zhang H, Trieflinger C, Daub J, Glasbeek $M$. Femtosecond fluorescence upconversion study of a boron dipyrromethene dye in solution. Chemical Physics Letters. 2003; 368: 66-75.

39. Harriman A, Hissler M, Ziessel R. Photophysical properties of pyrene-(2,2'-bipyridine) dyads. Physical Chemistry Chemical Physics. 1999; 1: 4203-11.

40. Zhou XF. 4,4-Difluoro-1,3,5,7-tetramethyl-8pentafluorophenyl-4-bora-3a,4a-diaza-s-indacene. Acta Crystallographica Section E. 2010; E66: 0757.

41. Dobkowski J, Rettig W, Waluk J. Intramolecular Charge- Transfer Properties of a Molecule with a Large Donor Group: The Case of 4'-(Pyren-1yl)Benzonitrile. Physical Chemistry Chemical Physics. 2002; 4: 4334-9.

42. Soultati A, Verykios A, Panagiotakis $S$, Armadorou KK, Haider MI, Kaltzoglou A, Drivas C, Fakharuddin A, Bao X, Yang C, Rashid bin Mohd Yusoff A, Evangelou EK, Petsalakis I, Kennou S, Falaras P, Yannakopoulou K, Pistolis G, Argitis P, Vasilopoulou $M$. Suppressing the Photocatalytic Activity of Zinc Oxide Electron-Transport Layer in Nonfullerene Organic Solar Cells with a PyreneBodipy Interlayer. ACS Applied Materials \& Interfaces. 2020; 12(19): 21961-73. 